the other strongly resembles ground pyrolized wood."

Because these two substances have "widely differing radiocarbon ages", the abstract says, "the radiocarbon age of the entire sample would yield results which are, at best, ambiguous." The UA scientists added: "We have been unable to find either of these two types of carbonaceous material in equivalent samples of these same petroglyphs when subsequently resampled independently."

Asked about these results, Dorn says he was not at either conference, requested copies of the papers and noted that other scientists also have found such substances when studying rock varnish. As examples, he cites an article published in 1961 by a Russian scientist, N. N. Karlov, who is said to have observed "a coal-black mineral substance" trapped under "desert lacquer" in the Black Sea region. He also cites a 1986 doctoral thesis by a researcher from Texas Tech University in Lubbock, who studied petroglyph surfaces in New Mexico and West Texas.

"I don't understand what all the fuss is about," says Dorn, who adds that he himself began publishing papers in 1996 questioning the interpretation of his own dating in previous articles. "The existence of the different types of material with different ages means

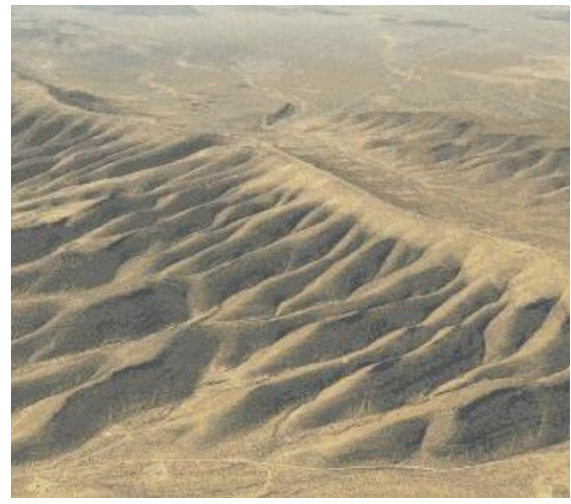

Yucca Mountain: data on landforms were used in the debate on a proposed nuclear waste site.

that prior results are very problematic."

But while Dorn says the content of rock varnish has been the subject of collegial scientific discussions for some time, his attorneys were involved last year in trying to prevent the UA scientists from publishing some of their findings, which were made about the same time that Dorn began seeking publication of his self-critical articles.

Stephen C. Porter, a University of Washington geology professor who is editor of the journal Quaternary Research, says he received a strongly worded letter last November from Dorn's attorney, who was seeking to block publication of an article after the UA scientists had offered Dorn co-authorship of it.

"The letter was rather intimidating," said Porter. "In 25 years as an editor, I've never experienced someone trying to prohibit publication prior to the review process." Dorn has since asked whether a full manuscript was submitted, says Porter, who adds that he never received the UA manuscript.

Porter identifies Dorn's attorney as Joseph N. Onek, who was Robert Gallo's attorney during his fight with the National Institutes of Health over a major HIV controversy. Onek has since moved to the US Department of Justice, according to a recent telephone message at his former law office. His science cases have been referred to another attorney, Robert P. Charrow. In a brief interview, Charrow made no comment, declining to acknowledge that he represented Dorn.

The forthcoming Science paper is expected to provide a new chapter in the debate, possibly determining the next step in Dorn's career, which has been studded with important awards, including the Geological Society of America's Kirk Bryan Award, of which he was a joint winner in 1986, and later an NSF Presidential Young Investigator Award.

RexDalton

\title{
Japan's genome programme goes ahead, with protein analysis
}

[токуо] Japan's largest and most advanced genome research programme will begin at the end of this year, despite an earlier dispute between its scientific advisers about whether it should become deeply involved in protein analysis.

The Genome Frontier Programme, now renamed the Biomolecular Research Programme, is being backed by the Institute of Physical and Chemical Research (RIKEN) and the Science and Technology Agency. It represents one of the latest efforts by the Japanese government to promote human genome research.

Support for genome research has grown dramatically in Japan over the past few years. The overall budget for the 1998 fiscal year, beginning 1 April, is one of the tightest for many years. But genome-related research projects across all science-related ministries and agencies saw a generous increase of more than double last year's figures (see Nature 391, 111; 1998).

But when details of the project designed to incorporate both DNA sequencing and protein analysis - were developed last year, some leading genome researchers acting as advisers were said to be opposed to proposals for the protein-related research project (see Nature 389, 772; 1997). They argued that only DNA base sequencing should be carried out, since genome research in Japan was insufficiently advanced, and the protein work would be premature.

But the government has now decided that the RIKEN programme will be carried out as originally planned. It will have three parts: DNA base sequencing using fulllength mouse complementary DNAs, the analysis of the human genome using chromosome 21 , and the analysis of protein function and structure.

Construction of the Biomolecular Research Centre, planned to be built in Yokohama, near Tokyo, is due to be completed in 2000, and there are plans to recruit at least 200 researchers. RIKEN also hopes to recruit 20 to 40 external researchers to participate in the project through a collaborative research system, and intends to accept proposals from overseas researchers in related fields.

The first five years of the 15-year project have recently been approved by the government. A sum of $¥ 4$ billion (US\$31 million) will be spent in the programme's first year, and a total of $¥ 50$ billion is planned to be invested over the five-year period.

Sequencing of full-length cDNA will be carried out using the latest automated highspeed sequencer developed by RIKEN, called RISA, for producing a genetic 'encyclopaedia' of gene and protein functions. The structure and function of proteins will be analysed using nuclear magnetic resonance (NMR) at a proposed
'NMR Park'(see Nature 381, 105; 1996) that has been incorporated into the new centre.

Part of the protein-related research will also be carried out at SPring-8, the world's largest third-generation synchrotron radiation facility, where RIKEN has two beamlines. The advanced features of the 8-GeV synchrotron, which began operation last October, are said to make it particularly useful for analysing protein structures.

Some leading genomic researchers claim the project is too ambitious because Japan is "several years behind the West" in genome research. Many also doubt the capabilities of RIKEN's new high-speed DNA sequencer, which is still under development.

But Akira Kira, the executive director of RIKEN, says that, although the technical aspects of the new sequencer have not yet been established, "we are optimistic about its potential". According to one project leader from RIKEN, RISA will help to minimize costs and could potentially carry out DNA sequencing at a much higher rate than commercially available models.

Akiyoshi Wada, former dean of science at Tokyo University and the director of Sagami Chemical Centre, says the project could potentially pave the way for Japan to join the front rank of international genomics research. But he warns that it will require careful management to fulfil its aims.

Asako Saegusa 